\title{
GASTROPROTECTIVE EFFECT OF ONION PEEL (Allium Cepa L. Var Ascalonicum) EXTRACT ON WISTAR RATS INDUCED BY MEFENAMIC ACID
}

\author{
Awalya Rahma Putri ${ }^{1}$, Dina Helianti ${ }^{2}$, Nindya Shinta Rumastika ${ }^{3}$
}

\begin{abstract}
${ }^{1}$ Faculty of Medicine, Jember University, Jember, East Java, Indonesia, ${ }^{2}$ Departement of Histology, Faculty of Medicine, Jember University, Jember, East Java, Indonesia, ${ }^{3}$ Department of Pathology, Faculty of Medicine, Jember University, Jember, East Java, Indonesia

${ }^{1}$ ma.awalya@outlook.com, ${ }^{2}$ dinahelianti.fk@unej.ac.id, ${ }^{3}$ shintariadi@ gmail.com
\end{abstract}

\begin{abstract}
Non Steroidal Anti-inflammatory Drugs (NSAID) have been implicated in the etiology of gastritis. Mefenamic acid is a non-selective NSAID used to treat mild to moderate pain and inflammation. Mefenamic acid induces gastritis through its inhibition of prostaglandin that results in increased $\mathrm{HCl}$ secretion, decreased mucin and bicarbonate ion production. This study aimed to investigate the gastroprotective effect of onion peel extract (OPE) against mefenamic acid-induced gastritis. In this study, the gastroprotective effect of OPE was examined through mucosal integrity scoring. A total of 28 male Wistar rats were divided into 4 groups, normal (Group 1), mefenamic acid+NaCMC 0,5\% (Group 2), mefenamic acid+OPE $600 \mathrm{mg} / \mathrm{kg}$ body weight (Group 3), and mefenamic acid+OPE $1200 \mathrm{mg} / \mathrm{kg}$ body weight (Group 4). All rats were sacrificed at day 15 then all gasters were collected. Histopathological examination was done under microscope with 100X magnification. Administration of mefenamic acid without OPE at all significantly increased gastric mucosal damage $(\mathrm{p}<0,05)$. Administration of OPE $1200 \mathrm{mg} / \mathrm{kg}$ body weight significantly decreased gastric mucosal damage $(\mathrm{p}<0,05)$. Group 4 show no significant difference $(\mathrm{p}=0,66)$ with the normal group (Group 1). This indicates that administration of OPE $1200 \mathrm{mg} / \mathrm{kg}$ body weight per oral ameliorates mefenamic acid-induced gastritis.
\end{abstract}

Keyword: onion peel, mefenamic acid, gastroprotective, gastritis, flavonoid

\section{Introduction}

Non Steroidal Anti-inflammatory Drugs (NSAID) are a type of drugs widely used to treat mild to moderate pain, such as menstrual pain [1]. The gastrointestinal issue has been known as side effects of NSAID usage [2]. Mefenamic acid is a non-selective NSAID that works by its inhibition to $\mathrm{COX}-1$ and COX-2 [3,4,5,6]. Inhibition to COX-1 decreased prostaglandin production on the gastrointestinal tract [2,6,7]. Prostaglandins are known as mucosal defense in gaster [6,7]. Prostaglandin works against the corrosive effect of $\mathrm{HCl}$ by inhibiting its production, increasing mucus and bicarbonate secretion, and maintain mucosal vascularity [7]. NSAID is one of the causes of gastritis. According to WHO (2015), the number of gastritis cases worldwide was 4.910.693. Gastritis is an inflammation of gastric mucosa marked by lymphocyte, and neutrophils infiltration, lamina propria edema, mucosal hyperemia, vasodilatation and erosion $[7,8,9]$.

Onion is the second-largest crop in Asia [10], nevertheless its non-edible part is rarely used. Allium cepa contain high flavonoid. Flavonoids from other plants are known to have antioxidant activity on various organs $[8,11,12,13]$. Previous research shows that phenolic compound and quercetin isolated from onion peel was 3 to 5 times higher than those from
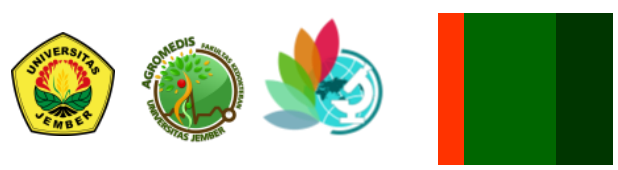
its edible part [14]. Ethanolic extract of onion peel shows higher total phenolic contents $(327.5 \mathrm{mg}$ GAE/g extract) and flavonoid contents (183.95mg QE/g extract) than extraction methods using hot water and subcritical water [15]. Flavonoid increases prostaglandin secretion thus increasing mucin and bicarbonate secretion, inhibit $\mathrm{HCl}$ secretion, and maintaining gastric mucosal vascularity [16].

\section{Methods}

A total of 28 male Wistar rats were used in this research. The rats were divided into four groups, Group 1 (normal control group), Group 2 (received only mefenamic acid), Group 3 (treatment with OPE $600 \mathrm{mg} / \mathrm{kg}$ body weight), and Group 4 (treatment with OPE $1200 \mathrm{mg} / \mathrm{kg}$ body weight). All rats were sacrificed on day 15 . Mefenamic acid was administrated orally to Group 2, Group 3, and Group 4 from day 1 until day 7. From day 8 until day 14, Group 2 was given $\mathrm{NaCMC} 0,5 \%$, Group 3 was given OPE 600 $\mathrm{mg} / \mathrm{kg}$ body weight, and Group 4 was given OPE $1200 \mathrm{mg} / \mathrm{kg}$ body weight. Meanwhile, Group 1 was given $2 \mathrm{ml}$ aqua dest as a stressor from day 1 until day 14 .

\subsection{Onion Peel Extract Preparation}

Onion peels waste were cleaned by soaking in saltwater and rinse thoroughly. Then onion peel was dried under the sun until it had crispy texture. Then onion peels were dried using iron baking sheet as the base. Dried onion peel was crushed using a food processor until it became powder. A total of 500 grams onion peel powder was soaked in ethanol $70 \%[15,17]$ until its volume reached $2,5 \mathrm{~L}$. This maceration process was repeated 3 times. The ethanol was changed with the new one every 24 hours. The ethanol-onion peel mixture was filtered using Whatman Paper No.2 [15] every 24 hours then the residual fluid was evaporated using a water bath at $50^{\circ} \mathrm{C}$.

\subsection{Mefenamic Acid Administration}

Mefenamic acid administration was done orally. Each rat of Group 2, Group 3, and Group 4 was given mefenamic acid 23,25 mg/day for 7 days in a row. Group 1 was given aqua dest 2 $\mathrm{ml} /$ day as equalization of stress.

\subsection{Treatment with OPE}

OPE was administrated for the following 7 days after mefenamic acid administration. Treatment was done orally by dissolving OPE in $\mathrm{NaCMC} 0,5 \%$. The volume used in this research was $5 \mathrm{ml}$ for every 1 kilogram of rats.

\subsection{Histopathological Specimen Preparation}

All rats were sacrificed on day 15 using ether. Gaster collected from each rat then stored in buffer normal formalin to get processed. Paraffin methods and Hematoxylin-Eosin coloring was used to make microscope preparation of corpus gaster. Data were collected using a modified scoring system from Barthel et al. (2003) [18]. Microscope preparation was judged from 10 fields of view. Modified Barthel et al. mucosal integrity scoring system mentioned are 0 (no pathological changes detectable); 1 (epithelial desquamation); 2 (erosion of the epithelial surface with gaps of 1 to 10 epithelial cells/lesion)); 3 (epithelial edema); 4 (mucosal ulceration with gaps of 10 epithelial cells/lesion). All specimens were observed under a binocular microscope with 100X magnification.

\subsection{Statistical Analysis}

Mean was used to test significance among groups using the Kruskal Wallis test. Then, Mann Whitney was used to finding which groups are significantly different from each other.

\section{Results}

The mean of the mucosal integrity score is increased in the Group 2. This indicated that the administration of mefenamic acid 23,25 mg/day causes gastritis and the physiological repair time of 7 days has not improved the damage to the gastric mucosal structure. Histopathological finding of Group 2 showed PMN infiltrate, lamina propria edema, mucosal erosion, and mucosal ulcer. A previous study conducted in reference [12] showed that the worst damage caused by $23,25 \mathrm{mg}$ /day mefenamic acid oral administration for 7 days in a row was mucosal erosion. Meanwhile, in this study, the same dosage of mefenamic acid caused mucosal ulcers in some fields of view.
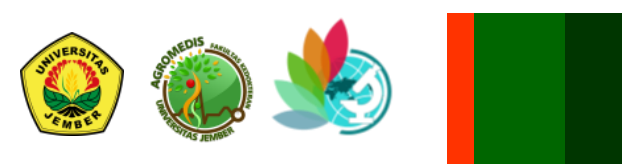
Group 3 that was administrated OPE 600 $\mathrm{mg} / \mathrm{kg}$ body weight showed better histopathological conditions than Group 2 . Infiltration of PMN were relatively lessen and there were fields of view that showed intact mucosa. However, Group 3 still showed epithelial edema and data were significantly different from Group 1. This indicates that administration of OPE $600 \mathrm{mg} / \mathrm{kg}$ body weight was able to repair gastritis induced by mefenamic acid but cannot reach a normal state.

Group 4 that was administrated OPE 1200 $\mathrm{mg} / \mathrm{kg}$ body weight showed intact mucosa. Gastric pits were easily observed and showed a normal histological condition. PMN infiltrates were observed to be much lower than those in group administrated with OPE $600 \mathrm{mg} / \mathrm{kg}$ body

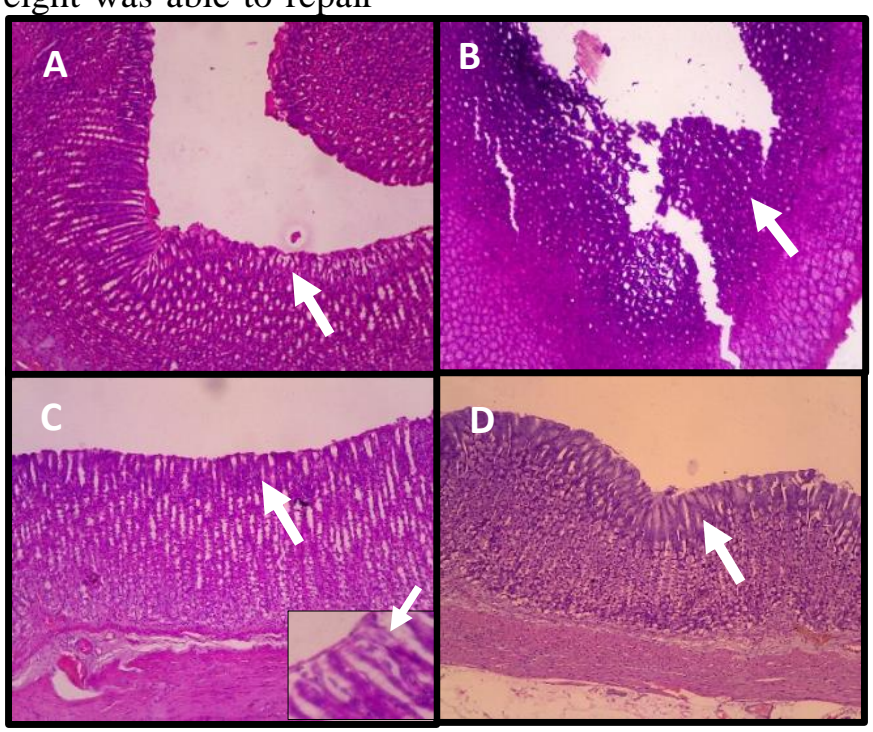

Figure 1. Photographs of sections of the gaster show the mucosal integrity. (A)Normal rats showing the intact gastric mucosa. (B) Gaster of gastritis rats show inflammatory cells infiltration and mucosal ulcers. (C) Gaster of gastritis rats treated with OPE $600 \mathrm{mg} / \mathrm{kg}$ body weight show intact gastric mucosa with epithelial cells edema. (D) Gaster of gastritis rats treated with OPE $1200 \mathrm{mg} / \mathrm{kg}$ body weight show intact gastric mucosa without edema or erosions.

Table 1. Gastroprotective effect of onion peel extract in rats induced by mefenamic acid

\begin{tabular}{lcc}
\multicolumn{1}{c}{ Groups } & Mean & SD \\
\hline Group 1 - normal & 0,41429 & 0,146385 \\
Group 2 - physiological & $1,61429^{\mathrm{a}}$ & 0,445079 \\
recovery & $1,05714^{\mathrm{ab}}$ & 0,293582 \\
Group 3 - OPE 600 & $0,70000^{\mathrm{b}}$ & 0,300000 \\
Group 4 - OPE 1200 &
\end{tabular}

$\mathrm{a}:$ data is significantly different $(\mathrm{p}<0,05)$ toward normal group (Group 1$)$

$\mathrm{b}$ : data is significantly different $(\mathrm{p}<0,05)$ toward gastritis group with physiological recovery process (Group 2)

weight. Data of Group 4 were not significantly different from the normal group. This indicates that administration of OPE $1200 \mathrm{mg} / \mathrm{kg}$ body weight was able to repair gastritis induced by mefenamic acid and managed to reach the normal state.

The Third Virtual Conference ICATD

\section{Discussion}

Mefenamic acid is non-selective NSAID that inhibit COX-1 and COX-2 [3,4,5,6]. This inhibition caused a lower rate of prostaglandin secretion $[2,6,7]$. Prostaglandin is a housekeeper for gaster [6,7]. If prostaglandin production is reduced, gastric mucosal defense becomes weak. 
Meanwhile, increased production of $\mathrm{HCl}$ is caused by an insufficient amount of prostaglandin to inhibit the process. Prostaglandin was meant to inhibit $\mathrm{HCl}$ secretion, increase mucin, and bicarbonate [6].

Flavonoid has shown its gastroprotective effect through antioxidant and radical scavenging ability [14]. The majority of researches about onion studied for its flavonoid activity in its edible part. The number of researches about its non-edible part or skin is still low. Yet phenolic and quercetin isolated from its skin were 3-5 times higher than its edible part [14].

Gastritis is not only caused by ROS but also the lower rate of prostaglandin [7,9]. This study conducted to show that flavonoids can also repair gastritis caused by lowered prostaglandin production. Flavonoid repaired gastritis through 2 pathways, increasing prostaglandin production and lowering $\mathrm{H}^{+}$ion secretion. Increased prostaglandin triggers mucin and bicarbonate to increase. $\mathrm{HCl}$ concentration in gastric lumen was lowered because bicarbonate binds the free acid and neutralize the gastric juice. Inhibition of $\mathrm{H}^{+}$ secretion by flavonoid caused a further decrease in $\mathrm{HCl}$ concentration. Lower $\mathrm{HCl}$ concentration was needed for gastric mucosal repair [16].

Thus, administration of onion peel extracts $1200 \mathrm{mg} / \mathrm{kg}$ body weight were able to repair gastritis caused by mefenamic acid and reach the normal state. Since mefenamic acid also can cause gastritis through ROS pathways, further research is needed to mitigate the use of OPE in gastritis as an antioxidant and radical scavenging using MDA and GSH as parameters.

\section{Acknowledgment}

There is no acknowledgment

\section{References}

[1] M. Soleha, A. Isnawati, N. Fitri, R. Adelina, H.T. Sobia, and Winarsih, 2018 "Profil penggunaan obat antiinflamasi nonsteroid di Indonesia," Jurnal Kefarmasian Indonesia vol. 8, pp. 109-117

[2] L.S. Goodman, dan A. Gillman. 2001, Goodman \& Gillman's The Pharmacological Basics of Therapeutics, $10^{\text {th }}$ ed. Connecticut: The McGraw-Hill Companies, Inc.

[3] A.N. Shafira, C.F. Kairupan, and M.F. Durry, 2016 "Gambaran histopatologik lambung tikus wistar (Rattus Norvegicus) yang diinduksi asam mefenamat dan diberi susu kental manis," Jurnal e-Biomedik vol. 4

[4] M. Hasan, 2016 "The effect of mefenamic acid on longitudinal development of growth plate in young male white rats," Journal of Agromedicine and Medical Sciences vol. 2, pp. $20-25$

[5] S. Setiati, I. Alwi, A.W. Sudoyo, M. Simadibrata, B. Setiyohadi, and A.F. Syam. 2014, Buku Ajar Penyakit Dalam, 6 ${ }^{\text {th }}$ ed. Jakarta: Interna Publishing

[6] N.J. Greenberger, R.S. Blumberg, and R. Burakoff. 2016, Current Diagnosis \& Treatment: Gastroenterology, Hepatology, $\&$ Endoscopy, $3^{\text {rd }}$ ed. New York: McGrawHill Education

[7] D.L. Kasper, A.S Fauci, S.L. Hauser, D.L. Longo, J.L. Jamenson, and J. Loscalzo. 2015, Harrison's Principles of Internal Medicine, $19^{\text {th }}$ ed. New York: McGraw-Hill Education

[8] J. Pasaribu, L.L Loho, and P. Lintong, 2013 "Gambaran histopatologik lambung tikus wistar (Rattus Noergicus) yang diberikan lengkuas (Alpinia galanga Willd) setelah diinduksi oleh asam mefenamat," Jurnal eBiomedik vol.1, pp. 402-407

[9] V. Kumar, A.K. Abbas, and J.C. Aster JC. 2018, Robbins Basic Pathology, $10^{\text {th }}$ ed. Canada: ELSEVIER

[10] M.S. Arshad, M. Sohaib, M. Nadeem, F. Saeed, A. Imran, A. Javed, Z. Amjad, and S.M. Batool, 2017 "Status and trends of nutraceuticals from onion and onion byproducts: A critical review," Congen Food \& Agriculture

[11] R. Dewi and R. Normasari, 2019 "Protective effect of cassava leaf extract on gentamicininduced hepatotoxity in mice," Journal of Agromedicine and Medical vol. 5, pp. 177182

[12] R. Sembiring, C. Kairupan, and L.L. Loho, 2017 "Gambaran histopatologik lambung
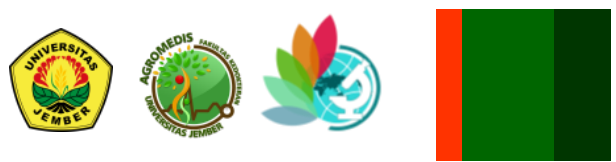
tikus wistar (Rattus Norvegicus) yang diberi sari buah nenas (Ananas comosus (L.) Merr) setelah induksi asam mefenamat," Jurnal eBiomedik vol. 5

[13] S.B. Almasaudi, N.A. El-Shitany, A.T. Abbas, U.A Abdel-dayem, S.S. Ali, S.K. Al Jaouni, and S. Harakeh, 2016 "Antioxidant, anti-inflammatory, and antiulcer potential of manuka honey against gastric ulcer in rats," Oxidative Medicine and Cellular Longevity

[14] M. Skerget, L. Majhenic, M. Bezjak, and Z. Knez, 2009 "Antioxidant, radical scavenging and antimicrobial activities of red onion (Allium cepa L) skin and edible part," Chemistry, Biochemical Engineering vol. 24, pp. 435-444

[15] K.A. Lee, K.T. Kim, H.J. Kim, M.S. Chung, P.S. Chang, H. Park, and H.D. Paik, 2014 "Antioxidant activities of onion (Allium cepa L.) peel extracts produced by ethanol, hot water, and subcritical water extraction," Food Science Biotechnology vol. 23, pp. 615-621

[16] W.H. Jiin, E.M. Hidayat, and K. Lukman, 2014 "Gastroprotective effect of carrot (Daucus carota L.) juice in rat models," Althea Medical Journal vol. 1, pp. 35-39

[17] M. Marelli, V. Amodeo, G. Statti, and F. Conforti, 2019 "Biological properties and bioactive components of Allium Cepa L.: focus on potential benefits in the treatment of obesity and related comorbidities," Molecules vol. 24

[18] M. Barthel, S. Hapfelmeier, L. QuintanillaMartinez, M. Kremer, M. Rohde, M. Hogardt, K. Pfeffer, H. Rüssmann, and W. Hardt, 2003 "Pretreatment of mice with streptomycin provides a Salmonella enterica serovar typhimurium colitis model that allows analysis of both pathogen and host," Infection and Imunity vol. 71, pp. 28392858 